\title{
An assessment of Key Success Factors for Construction Projects in the Democratic Republic of Congo
}

\author{
Adrien Fariala ${ }^{1} \&$ Olawumi Dele Awolusi² \\ ${ }^{1}$ Department of Business Administration, the Business School, University of Roehampton, London, UK \\ 2Department of Accounting and Finance, College of Economics and Management, Kampala International \\ University, Kampala, Uganda \\ adrien.fariala@roehampton-online.ac.uk, awolusi.olawumi@kiu.ac.ug
}

\begin{abstract}
The success of the Government's construction projects in the Democratic Republic of Congo (DRC) since 2011 has been anchored on the potential of construction firms in completing these projects based on the planned timeframe as well as the budget. Consequently, from a project management viewpoint, the main objective of the present study was to assess the critical success factors in developing countries' construction projects and to examine the impact of risk management, leadership, experience and expertise, and project size on construction projects in DRC. Data was gathered from respondents in the construction projects in DRC using quantitative methods. A statistical software program, SPSS version 25, was subsequently used to analyze the collected quantitative data. The findings emanating from this study contribute to the body of knowledge on key success factors in construction projects in DRC as a developing country. It was revealed from the study that the success of construction projects in DRC could be boosted through effective and efficient risk management. In addition, effective and efficient leadership mainly transactional leadership would affect construction project success. Further, the more the experience and expertise of construction project staff, the more likely the project success criteria would be met, and the more likely the project would be successful. And lastly, smaller-sized and medium-sized construction projects may be more successful, whereas mega projects may not be very successful due to insufficient and limited experience and expertise.
\end{abstract}

\section{Keywords: Critical Success Factors, Developing Country, Least Developed Countries, Project Success, Quality.}

\section{Introduction}

This study assessed key success determinants in developing countries' construction projects with particular emphasis on the Democratic Republic of Congo (DRC) construction industry. The construction industry plays a vital role in developing countries and contributes significantly to the growth of socio-economy development and employment (Awolusi, 2021; Mahmood and Shahrukh, 2012). This is applied in DRC as well. DRC is a central African Francophone nation, as shown in appendix 6 whose population is approximately 78 million and covers an area that spans 2.345 million $\mathrm{km}^{2}$ (United Nations, 2018). The DRC is the second biggest country in Africa; the country is larger than the combined area of Norway, Sweden, Germany, France and Spain (Chepkemoi, 2018). The country is the largest producer of cobalt ore and the second producer of diamond in the world according to the report by Chepkemoi (2018). The DRC government has launched several construction projects since 2011 with the aim of development and the emergence of the country using the concept of "revolution of modernity" (ANAPI, 2016). These projects are still ongoing today, and many are waiting for funds from investors.

However, as explained by Niazi and Painting (2017), the major concern for construction industry stakeholders is the frequency of inability of project implementers in completing projects within time and budget scope (Olayisade \& Awolusi, 2021). Successful developmental projects are not entirely dependent on one but on several key success determinants and numerous studies have been undertaken to establish the possible factors that could be contributing to success in construction projects (Serrador and Pinto, 2015). Managing the particular determinant that contributes to success in construction projects significantly influences how a project meets the quality, cost and time dimensions which are parameters against which a successful project is weighed (Gunduz and Yahya, 2015). According to Mavetera et al. (2015), investigators have made attempts to establish success determinants that may be used in refining the evaluation of construction projects. Even though the economic development of developing countries depends on the successful implementation of new infrastructure projects, the planning and execution of construction projects have not been adequately achieved (Rajasekaran and Valli, 2014). 
In addition, Gunduz and Yahya (2015) mention that most construction projects in developing nations, where economies are low, do not meet the success criterion for construction projects. According to Gunduz and Yahya (2015), the majority of projects incur cost overruns way beyond the scheduled time and are often of poor quality. Efforts have been made by various scholars and practitioners alike to pinpoint key determinants for successful construction projects to improve their success (Alashwal et al., 2017). Nevertheless, due to the complexity of construction projects, there has never been a single conventionally accepted collection of critical success factors (CSFs). Furthermore, findings of studies from developed countries are deemed to be unsuitable for generalizing in the least developed countries, and most notably, for unstable economies such as the DRC. In addition, the majority of the studies that have been done and attempted to establish critical determinants associated with successful construction projects have their context based on more industrialized countries (Kogan and Lee, 2014; Iram, Khan and Sherani, 2016; Alashwal et al., 2017). Despite construction constituting one of the pillars of the economy in developing countries, there are limited studies that have been undertaken to evaluate CSFs of construction projects so that that their success rate can be improved (Damoah, Akwei and Mouzughi, 2015). Silva, Warnakulasuriya and Arachchige (2016) note that identifying and carefully controlling key success determinants may have the desired result on construction projects and improve their success rates.

Different fields have delved into studying CSFs stemming from Rockart's 1981 theory of CSFs which states that a project has a limited number of key areas which if managed effectively ensure the success of a project (Ramlee et al., 2016). In light of the preceding discussion, this study investigated key determinants for successful construction projects in the least developed countries and in particular, DRC. The DRC government invested heavily in construction projects such as the building of new infrastructure given the country's economic emergence (ANAPI, 2016). For example, the construction of the modern city Kinshasa which budget is around USD 15 billion. This includes constructions of hospitals, schools, buildings, roads, shopping centers, while the construction of the biggest Hydro Power Project Inga 3, will cost nearly USD 13.5 (Clowes, 2018). However, most of these projects tend to slow down or fail to meet the success parameters of quality, cost and time which are scheduled at the outset of these development projects (World Bank, 2018). We believe that they are many reasons which lead to a project failing in DRC such as risk management, experience, expertise, etc. The identification of key success factors will furnish project participants with a key indicator to succeed in projecting the least developed countries in general and particularly in DRC. In the construction industry, stakeholders are utterly concerned with the failure of projects being completed within the defined scope of budget and time, and whereas there is a common problem globally related to cost overruns, it is posing a unique challenge for developing nations (Niazi and Painting, 2017).

Different studies have been conducted and aimed to identify project success factors and the root cause of their failures (Yong \& Mustaffa, 2013; Gunduz \& Yahya, 2015; Doulabi \& Asnaashari, 2016; Williams, 2016; Alashwal, Fareed \& Al-obaidi, 2017; Aneesha \& Haridharan, 2017; Banihashemi et al., 2017). Some of these studies identified success factors for construction projects, but few focused on key success factors. Our Studies will focus on the key ones that may affect the project in developing countries. Consequently, this present study sought to investigate how key success determinants of risk management, leadership, experience, expertise, and project size influence successful building projects in DRC. The study's core objective was to find out the factors that influence successful construction projects in DRC. The aim was to undertake a quantitative study upon which the state of construction projects in DRC would be laid bare and subsequently allow for generalizing to other developing and least developed nations. However, the specific objectives of the study were to;

i. Examine the influence of risk management on construction projects in DRC.

ii. Examine the influence of leadership on construction projects in DRC.

iii. Establish the influence of experience and expertise on construction projects in DRC.

iv. Examine the influence of project size on construction projects in DRC.

The specific research questions of the study were to find out;

i. How does risk management influence construction-related projects in DRC?

ii. How does leadership influence construction-related projects in the DRC?

iii. How do experience and expertise influence construction-related projects in DRC?

iv. How does project size impact construction-related projects in the DRC? 
To establish the influence of these critical success determinants on construction-related projects in DRC, the above-stated research questions were answered via the collection of data in a field study and analyzing the information gathered. It is also important to note that, other researchers focused on developing nations like Ghana, Malaysia and South Africa but none has been done in countries like DRC, Soudan, Zambia and others which are classified as LDCs by the United Nations (Tesfaye et al., 2017). The LDCs have many challenges compared to other developing countries such as acute poverty, weak human capital, lack of expertise and skills (Development Policy and Analysis Division | Dept of Economic and Social Affairs | United Nations, 2018). This study would be of great importance to academia by making a contribution to the literature regarding project management while offering students the opportunity for converting learned theory into practice. In addition, the results would assist the business sector and investors in making appropriate and desirable adjustments to project management programs. The assessment results of CSF will benefit Project managers and teams working in developing countries and LDCs as the study provide determinants that are crucial in successful construction projects. This will improve their skills and awareness of what needs to be considered while doing a project in developing countries and particularly in LDCs.

\section{Review of Related Literature}

Conceptual Review: Successful construction projects are defined based on some standards, such as critical success parameters (Tesfaye et al., 2017). Studies on this subject in developing countries are scanty and due to the historic under the development of the country. The aim of this study is trying to build upon literature concerning key success indicators in construction projects for developing countries with emphasis on DRC. Success in construction projects rests with the implementation of various features effectively. Project management practice, according to Alias et al. (2014) and Silva, Warnakulasooriya and Arachchige (2015) has the potential of influencing the success of a construction project whether directly or indirectly. Pinto and Slevin (1988) are wary that there are in-depth studies on factors that influence successful projects in developing countries that are inadequate, a matter that this study tried to address. In the evaluation of factors that influence successful construction-related projects, the emphasis has to be made, and distinction is made between success factors and success criteria (Crawford, 2000; Tesfaye et al., 2017). Sanvido et al. (1992) consider a successful project like that which fulfils certain expectations of the project stakeholders. The "iron triangle" (Barnes, 1988) is the preferred success benchmark for construction projects in third-world countries. The "iron triangle" criterion explicitly emphasizes the dimensions of quality, cost and time. According to Ojiako, Johansen and Greenwood (2008), this framework defines successful projects as those who meet set quality, are completed within the planned time as well as the budgetary cost. Although this framework provides the basis for evaluating successful projects, developing countries have unsuccessfully met this criterion (Long et al., 2004). The conceptual framework is shown in figure 1.

Figure 1: Conceptual Framework

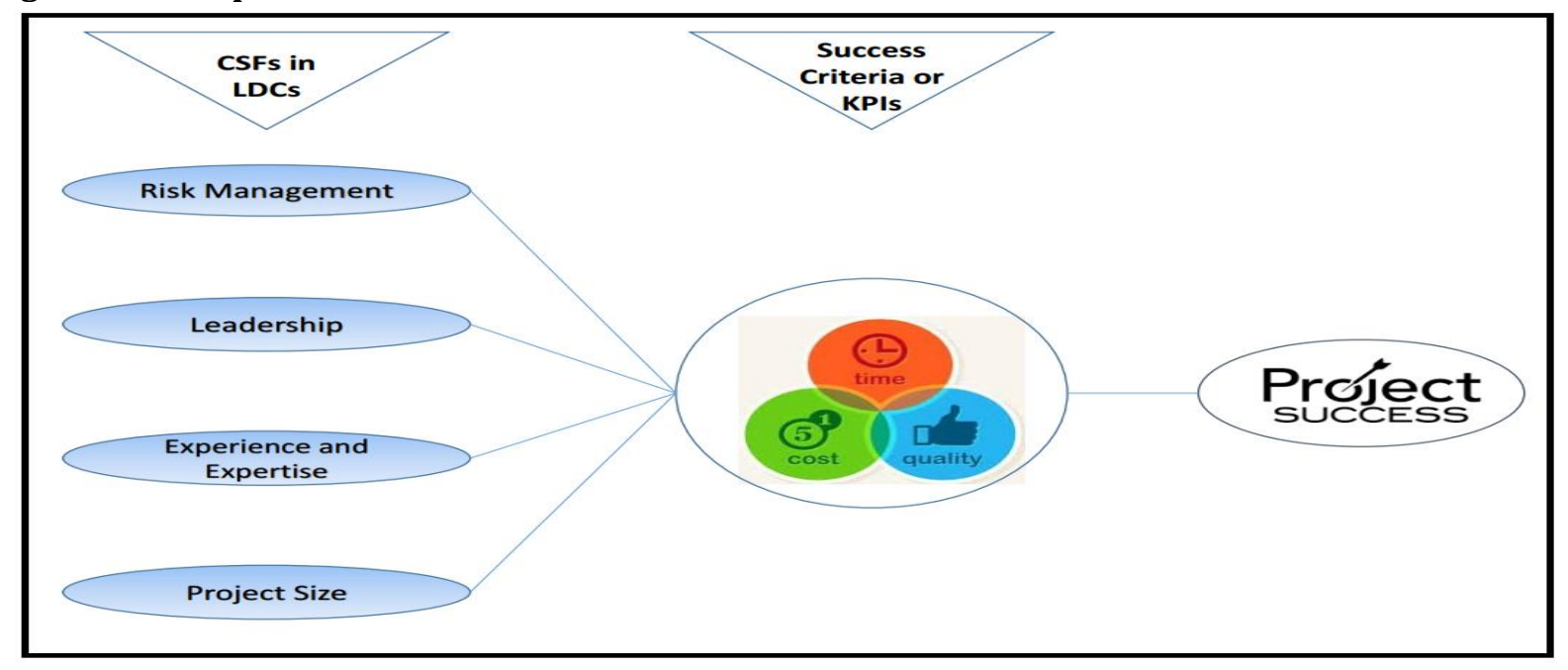

Source: Authors Own 
To establish the key success determinants for construction projects in DRC, the researcher used the quantitative research method (Saunders, Lewis and Thornhill, 2012). The study participants responded to a structured questionnaire to which numeric data were collected to help address the research questions. The researcher computed descriptive statistics, inferential statistics and performed correlation analysis (Weiers, 2011) using SPSS.

Theoretical Review: The present study is grounded on the following theories: Principal-Agent Theory (Ceric, 2013); Contingency Theory (Hattangadi, 2016); and Systems Theory (Chikere and Nwoka, 2015; Hattangadi, 2016). The Principal-Agent Theory (Ceric, 2013) is based on the tenet that the agent can make decisions for the owner (principal) in any business or economic transaction. According to Ceric (2013), the Principal-Agent Theory is rooted in information asymmetry, such that one party (agent) is more informed than the owner while not sharing similar interests, and as a result of this, opportunistic behavior can be expected in such relationships (Ceric, 2013). In this study, the construction companies are contractors (agents) for the government and private owners (principals) of construction projects in the DRC. Therefore, to better understand this study, the researcher draws on the Principal-Agent Theory. George Akerlof, Michael Spence, and Joseph Stiglitz contributed tremendously in the 1970s to develop the information asymmetry theory on which the Principal-Agent Theory is based. In this study, the construction companies are contractors (agents) for the government and private owners (principals) of construction projects in the DRC. Figure 2 shows the Principal-Agent Theory framework for construction projects. According to the model, the project owner (PO) relates to the contractor (C) in a business relationship that involves various economic interests. There is often a designer (D), a project owner's project manager (Papo), a designer's project manager (PMd), and a contractor's project manager (PMc) as shown in Figure 2. Therefore, to better understand this study, the researcher draws on the Principal-Agent Theory.

\section{Figure 2: Principal-Agent Theory Framework for Construction Projects}

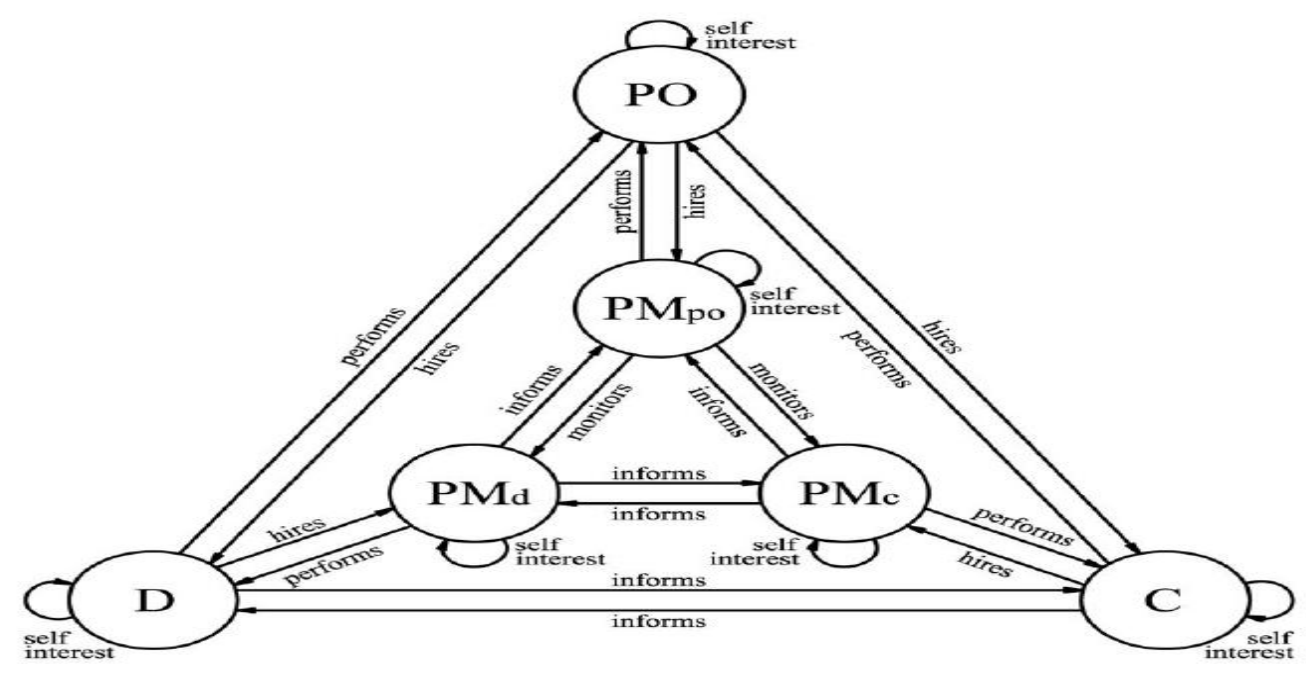

Source: (Ceric, 2013)

The Contingency Theory: Postulates that no best cause of action in running a business exists and that organizing, leadership or decision making is contingent on the internal and external situation. According to Hattangadi (2016), organizations ought to take into consideration the prevailing situation before making decisions on issues related to distributors, suppliers, unions, technology, consumer interest groups, government, customers and competitors. Wadongo and Abdel-Kader (2014) explained when applied during decision making; this theory may enhance management in performance. In this study, decision-making choices in construction companies in the DRC will be studied relating to distributors, suppliers, unions, technology, consumer interest groups, government, customers and competitors. Consequently, to better understand this study, the researcher draws on the contingency theory. 
The Systems Theory: Views an organization as a composition of interrelated organs and that organization's relationship with their environments (Chikere and Nwoka, 2015; Hattangadi, 2016). The theory is a transdisciplinary theory that was developed in the 1950s by Ludwig von Bertalanffy (Hattangadi, 2016). This theory applies to the current study as construction firms in DRC are organizations made up of interrelated organs or branches that have to relate with the society, government, and stakeholders (environment). Therefore, to better understand this study, the researcher draws on the Systems Theory. Construction projects are operated on a systematic level, with various stakeholders playing different roles towards one goal. The incorporation of the systems theory will help to study the interrelatedness of different stakeholders' activities and their contribution towards the success of construction projects.

\section{Empirical Literature Review}

Key Success Indicators in Construction-Related Projects: The scope of construction is very diverse, and similarly are success determinants in construction projects. Silva, Warnakulasooriya and Arachchige (2015) assert that despite the identification of various key success factors, there is a lack of consensus among scholars on agreeable factors as they take different dimensions. The implication for this is that depending on the framework chosen; the factors could be defined either broadly or narrowly. More so, the authors go on to state that CSFs would most likely differ from one country to another as a result of country-specific operating environment, policies and legal constraints. Silva, Warnakulasuriya and Arachchige (2016) evaluated published literature in journals to analyze key success determinants in the construction industry. The findings revealed a host of 34 internal determinants and 40 external determinants. Further, the study established that there was a repetition of 19 internal determinants and 10 external determinants in at least 3 papers. The factors explored in this study suggested that external factors such as environment and inherent determinants like the projects' nature contribute to successful projects regardless of their position. The inclusivity of this study addressed issues affecting all stakeholders on all phases of a construction project. Therefore, it would perhaps be significant noting that the findings of studies which are conducted in developed countries may be suitable for neither generalizing nor being sufficient to represent the situation in the developing countries and as such, they need to examine such factors in the context of developing countries.

Risk Management: Traditional, the concept of risk has been perceived as being associated with negative, and many people traditionally view risk as exposing to danger or hazard. However, in project management, project risk is considered as an occurrence that is uncertain and which can either positively or negatively impact the project goals such as its quality, cost, schedule or scope (Hosny, Ibrahim and Fraig, 2018). Risk management encompasses the mitigation of project or organizational risks by the management (Abd ElKarim, Mosa El Nawawy and Abdel-Alim, 2017). PMI identifies four fundamental risk management steps, and these include "risk identification, risk analysis, risk response planning, and risk monitoring and control" (Project Management Institute, 2013). Even though other scholars have shown fewer numbers of steps for risk management, its importance in construction-related projects cannot be undermined. In another study, Tsiga, Emes and Smith (2017) explained the significance of managing risks in petroleum projects. They explained that multinational corporations should embark on risk management for diverse cultures while undertaking projects globally. Tengan and Aigbavboa (2017) explained the importance of undertaking monitoring and evaluation exercises to mitigate risk and enhance the success of projects. Similarly, effective risk management is imperative for any successful building construction project (Odimabo and Oduoza, 2018). Consequently, we hypothesize that

$\mathbf{H}_{1}$ : risk management affects the success criteria for construction-related projects in DRC.

Leadership: Leadership is an influential process that can help move an organization or project move forward (Aritz and Walker, 2014). The Least Developed Countries (LDCs) are characterized by weak human capital, and there is a need for leadership development in these countries, such as the DRC. Men (2014) found that authentic leadership development is pivotal in nurturing the communication system which can enhance a projects' success due to transparent communication practice, accountability, and employees' positive evaluation of the entire organization. In addition, Joo and Nimon (2014) recommended that HR departments should develop leadership development programs that incorporate both authentic leadership development and transformational leadership development in a concerted manner. According to Giltinane (2013), in 
return for compliance, followers being rewarded is what characterizes transactional leadership. This type of leadership could positively affect the satisfaction as well as the performance of subordinates if the rewards are contingent. The focus of a leader exercising this form of leadership is majorly on management tasks, and as a result, he/she may not identify a team's shared values (Giltinane, 2013).

On the other hand, transformational leadership realizes the importance of the potential of followers as well as recognizing the need to satisfy their higher needs. Burns conceptualized transformational leadership in 1978 (Gözükara and Şimşek, 2015). A transformational leader is viewed as inspiring followers to achieve more while at the same time, motivating the followers in achieving high ideals and goals. According to the survey by Liphadzi, Aigbavboa and Thwala (2015) in South Africa, successful projects are influenced by transactional leadership. The authors noted that the laissez-faire style of leadership does not influence successful construction projects as there is no relationship between the two. It may, therefore, be argued that the style of leadership influences successful construction projects. Consequently, that

$\mathbf{H}_{2}$ : Leadership affects the success criteria for construction-related projects in DRC.

Experience and Expertise: Niazi and Painting (2017) state that poor contractor experience in a development project is a factor that results in cost overruns. In addition, Hosny, Ibrahim and Fraig (2018) explained that design complexity, time compression, availability of resources, team size, management stability, experience and history affect risks in construction. Further, Baron and Parent (2015) suggest the training of business leaders to enhance their expertise and make them authentic leaders. Large development projects often involve multinational corporations as contractors. Thus, Rezek (2013) explains that business leaders ought to become authentic and effective in facing culturally diverse markets. In another study, Wondimu et al. (2016) identified the qualification of contractors and competence of project owners as success determinants in building projects. Further, Wondimu et al. (2016) stated that the management of projects should take into consideration the mixing of cultures across the globe and, therefore, the multicultural experience is vital in the management of projects across countries. Araszkiewicz (2017) explained the importance of effective and efficient portfolio management by companies. We, therefore, hypothesize that

$\mathbf{H}_{3}$ : Experience and expertise influence the success criteria of construction projects.

Project Size: Ramlee et al. (2016) explain that the size of past projects completed may influence successful other projects. The authors also state that company image, waste disposal, adequate plant resources and labor, quality policy and turnover history significantly affect the success of projects. Similarly, Das and Ngacho (2017) explain that unique characteristics of construction projects about their control, scheduling, planning, complexity and nature collectively determine a project's success. Nzekwe et al. (2015), argue that regardless of the project size, the project manager can always succeed if they have carefully planned their project. Misic and Radujkovic (2015) explained the problems associated with huge or mega projects. According to the authors, large is risky, with over $50 \%$ of cost overruns, and turn to have a delivery failure as high as $66 \%$ and these projects may not produce the intended societal benefits. In addition, Mišić and Radujković (2015) stated that the key players of every project are people and that the delivery of mega projects requires competent project managers. Consequently, project size may affect construction projects' success in less developed countries. In another study, Belay and Torp (2017) found that cost deviation is not associated with longer. Consequently, the present study, therefore, hypothesized that

$\mathbf{H}_{4}$ : Project size affects the success criteria of construction-related projects in DRC.

Success Criteria: The universally accepted measures used in evaluating a successful project are referred to as success criteria. According to Alias et al. (2014), the CSFs in a construction project based on the "iron triangle" framework include quality, time and cost. The dimension of time is strongly supported by Zidane et al.(2015) who stated that effective and efficient use of time is a key determinant of a construction project that is considered successful. Alias et al. (2014) describe CSFs as project management inputs that may lead to successful projects, whether directly or indirectly. In another study, Tsiga, Emes and Smith (2017) explained the need for distinguishing between success criteria and success factors. Whereas success criteria constitute measures that we use to judge the success or failure of the project, success factors refer to inputs in a project and which strongly influence a project's success and therefore call for their management (Tsiga, Emes and Smith, 2017). However, Das and Ngacho (2017) state that complex construction projects have their CSFs 
evaluated using the traditional measures of quality, cost and time. Further, the authors critique the traditional model of the evaluation criteria of success of a project by noting that this criterion fails to adequately consider social and environmental concerns of the society and therefore cannot be taken as ensuring the completeness of a successful project. Consequently, using factors like risk management, leadership, experience and expertise, and size of the project developing countries would be a better measure to use in evaluating the success of construction-related projects.

Critical Success Determinants and Success Criteria: Project risks can result in a slowdown of a construction project that would eventually result in cost overruns (El-Karim, El Nawawy and Abdel-Alim, 2017). Further, the study in the South African construction industry by Liphadzi, Aigbavboa and Thwala (2015) on the association between leadership styles and success of a project established that transaction leadership style influenced successful projects on scheduled delivery, budgeting, and quality of a project. Further, Niazi and Painting (2017) stated that poor contractor experience is a factor that results in cost overrun in development projects. Hosny, Ibrahim and Fraig (2018) concurs with this view and states that experience and expertise affect project quality, cost, and schedule. Lastly, Das and Ngacho (2017) explained that the complexity and size of a project affect successful projects on cost, delivery time, and quality.

Project Success: Project success refers to meeting the expected results or even over-performing in project delivery (Ramlee et al., 2016). Ramlee et al. (2016) note that whereas common universal measures are quality, schedule and cost, each project has its success criteria. Although the concept of project success is somewhat controversial based on non-agreement about what constitutes standard key success determinants for construction-related projects (Ramlee et al., 2016). As explained by Montequin et al. (2016), project success is not necessarily meeting cost, deadlines and specifications. The satisfaction of a client with the final delivery depends more on the perception of the success or failure of a project. Critical success determinants have proven to impact directly on the criterion for success on all three criteria of a construction project's success.

Conceptual framework: Figure 3 presents a selection of four CSFs in the least developed countries (LCDs) like DRC is shown on the left-hand side. The universally accepted parameters for success are in the middle of the figure, and the projects' success is shown on the right-hand side. In the model, the key success determinants and how they affect the parameters based on the "iron triangle" are illustrated. These success determinants were identified based on the review of several studies (Damoah, Akwei and Mouzughi, 2015; Gunduz and Yahya, 2015).

Figure 3: Conceptual Framework

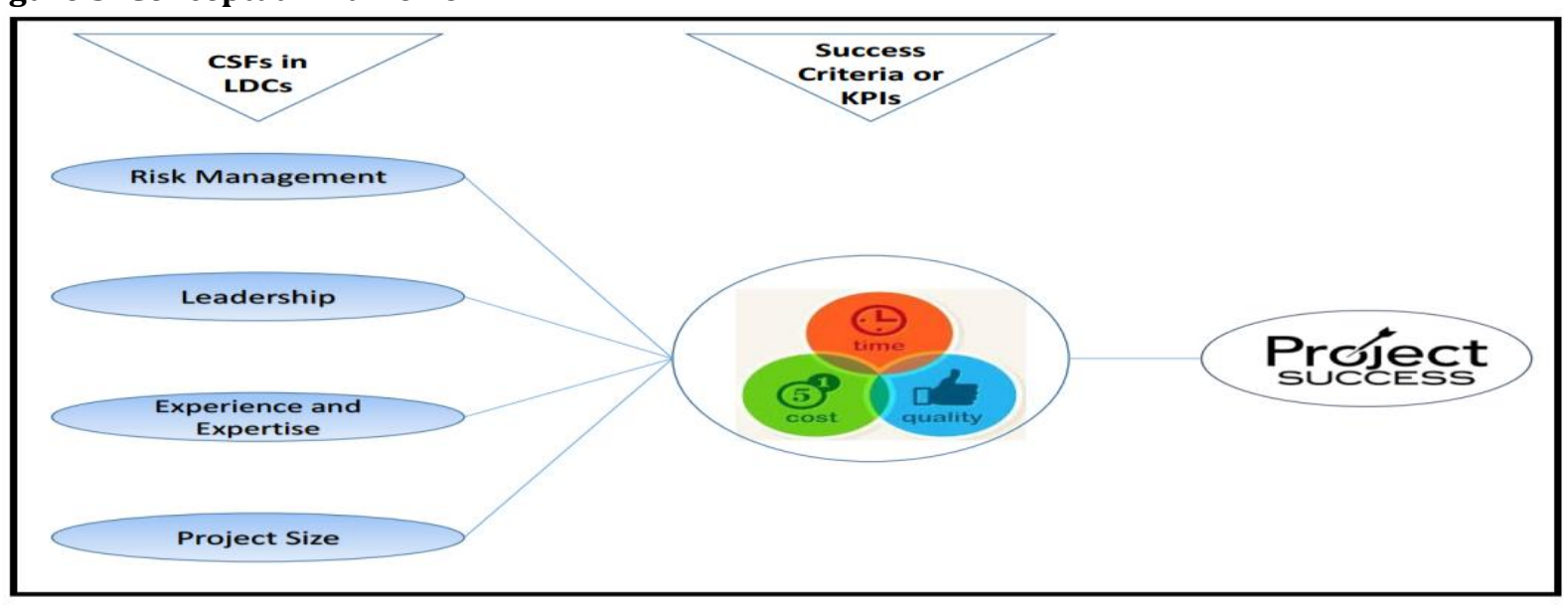

Source: Authors Own

Gaps in Literature: Based on a review of related literature, it has become evident that there is inadequate literature about construction projects' CSFs in the least Developed Countries (LDCs). The Democratic Republic of Congo is among the developing countries but classified under the LCDs, according to the United 
Nations Report in 2018, as shown in appendix 5. Previous studies on this subject focused on such countries as South Africa Malaysia, Nigeria, Sri Lank, Ghana (Cheong Yong and Emma Mustaffa, 2012; Afolabi et al., 2019; Risath and Siriwardana, 2018; Babalola and Ojo, 2016; Odimabo and Oduoza, 2013; Tshik, 2015), Which are not classified as Least Developed Countries. This shows that in the least developed countries, studies investigating key success factors in building-related projects are scanty. The literature reviewed shows that all the studies have either been conducted in the developed world or the developing world but none in the specific region of LDCs and hence the need for the current study being conducted in DRC.

The researcher has also found out through reviewing the existing literature of the absence of a clear-cut framework that LDC practitioners can refer to implement successful projects. The area of framework development has been underexplored or neglected by previous researchers. This study will aim to generate data that can be transformed into relevant frameworks for practitioners in the industry. The current body of knowledge only offers dispersed information that does not provide a unified framework that can be adopted by LDCs. Lastly; the reviewed studies have failed to thoroughly explain how each of the success criteria is affected by the CSFs. Most of the studies have grouped the success criterion simply as success without carefully putting separating each criterion and presenting data on how it is affected by a particular CSF. By successfully aligning success criteria and certain CSFs, practitioners can easily locate which CSFs to alter based on the affected success criterion.

\section{Methodology}

The study was carried out at 17 construction companies in the DRC. Construction companies of different cities were targeted to have a general idea of challenges from different corners of the country. The cities selected for this study were Kinshasa, Lubumbashi, Kolwezi, Bukavu, Goma and Kisangani. According to Adams, Khan and Raeside (2014), a research design is a plan by the researcher that helps in the fulfillment of the objectives of the research besides ensuring that the collected data is suitable for addressing the stated problem. Akeke, Akeke and Awolusi (2015) note that researchers can use different forms of research designs that include but are not limited to descriptive, explanatory and exploratory. The researcher, a descriptive research design. In descriptive research design, a researcher gathers data whilst not tampering with the environment (Saunders, Lewis and Thornhill, 2012). The researcher opted for the quantitative approach while utilizing survey questionnaires as the primary method for soliciting data. As stated in Easterby-Smith, Thorpe and Jackson (2012), quantitative methods are ideal for investigating phenomena that cannot be analyzed through the personal experiences of people. Quantitative research approaches aim to investigate a phenomenon as it applies to the majority of the investigated population (Awolusi, 2012).

A population comprises units that share a similar set of attributes or traits (Zikmund, 2010). According to the author, a population includes all members that a researcher has got interested in and consists of the entire set of observations being considered in a study. The target population of this study was comprised of all the staff members of construction companies in the DRC. This population was estimated at 5000 staff members. However, the accessible population was only about 200 staff members, and the researcher used a sample of this accessible population. Weiers (2011) defines sampling as the systematic extraction of members of a population to gather useful data regarding the entire population. The author further states that a subset that is obtained from the population is referred to as a sample. Saunders, Lewis and Thornhill (2012) identify sampling techniques as either random or non-random. While probability concepts are applied in selecting study participants in random sampling, this probability is not attached when a non-random sampling technique is utilized. Edwards and Holland (2013) suggest that probabilistic sampling can be used in quantitative research. The authors stated that a sample should furnish the most helpful data for addressing the research objectives (Edwards and Holland, 2013).

Saunders, Lewis and Thornhill (2016) explicitly state that probability sampling ensures that any item on the sampling frame stands a chance to be selected and used in a study. The authors state that this randomness implies a basic argument in the generalization of research studies. Concurring with the previous statement, Leedy and Ormrod (2015) explain that a quantitative study can use both sampling techniques, but when selection is being done, probability sampling should take precedence. The researcher employed probability sampling as respondents were selected from a sampling frame in the form of a company staff directory (Eze \& 
Awolusi, 2018). The author sent emails to the respondents and only used the respondents that replied to the mail, and in doing so, the researcher used a non-probability sampling technique called convenience sampling (Saunders, Lewis and Thornhill, 2016). The researcher selected 17 construction companies out of the over 500 construction companies in the DRC based on their location in the country and then applied to the companies for permission to conduct this study. Some companies are not purely construction but are involved in construction projects across the country. The applications, as well as authorization letters for undertaking the study, are annexed in the Appendices section. The first 17 companies that replied and were granted the opportunity to collect data were included in the study.

The selection of 17 companies helped the researcher to cover the different parts of the country that have different challenges. Then the researcher sent out 10 to 20 emails to selected staff members on each of the 17 company's directory and also travelled from different corners of the country to explain to staff members about the questionnaires. The letter of invitation to staff members to participate in this study is shown in the Appendix. The researcher requested the staff to voluntarily join the study and also introduce other suitable staff members in their respective companies to join the study. The first 10 staff members of each of the 17 companies that replied to the invitation for participation in this study were subsequently recruited. The questionnaires were both in French and English; the staff did choose to answer any of their preferred languages. The sampling technique used was non-random because the researcher wanted to establish contact with the most suitable construction companies and staff members. The researcher had 10 respondents from each of the 17 companies making a total of 170 respondents. Saunders, Lewis and Thornhill (2012) explain data collection is a process of collecting useful data during a research project. Quantitative data were obtained through a structured questionnaire that was distributed to staff members at the 17 companies involved in construction in the DRC shown in the Appendix.

As explained by Collis and Hussey (2003), questionnaires are well-known research tools that are composed of a set of well-articulated and proven questions aimed at inducing trustworthy responses from a research subject. Further, Collis and Hussey (2003) explained that questionnaires facilitate the collection of bulk data and are less time-consuming than interviews. Even though the use of online questionnaires to collect data has advantages such as access to unique populations and timeliness, the researcher used email and handed hard copy questionnaires because not all staff members have access to the Internet at all times. The researcher emailed copies of the questionnaire to staff members at the company offices and travelled across DRC for data collection. During the data collection exercise, each research respondent had ample time to read and respond to the same questionnaire at a convenient time and his understanding language, either French or English. The introductory page of the email questionnaire contained the aim of the research and the guidelines for responding to the questions. The researcher used a 5-point Likert scale during the construction of the structured research instrument (Likert, 1932). The Liker scale can be used to measure a sample's behavior in terms of attitudes and perceptions (Likert, 1932). The research respondents were asked to agree or disagree using five-point scales of attitude measures, and the scores were processed by calculating measures of dispersion and central tendency (Brace, 2008).

Thus, the researcher used the email questionnaire method and distributed the questionnaires to employees to obtain data. Yujin (2011) refers to a pilot study as one where the research instrument is tested on a small scale to gauge its validity and reliability. Flaws in the formulated research instrument were identified by selecting a construction company to test the questionnaire before initial data collection. The researcher collected pilot data from a construction company that was excluded from the real data collection exercise. The pilot study feedback was examined to check the limitations as well as flaws of the research instrument. The final research instrument had been adjusted accordingly, based on the feedback of analysis of the pilot study. Data analysis is a statistical procedure in which data is organized, summarized and presented as information (Adeer, Mellenbergh and Hand, 2011). The researcher analyzed the data by computing "inferential statistics" (Weiers, 2011). As explained by Weiers (2011), inferential statistics involves reaching conclusions that go beyond the sample data alone, such as trying to make conclusions based on the sample data on what opinions of the entire population might be about the topic (Weiers, 2011). Also, inferential statistics can help the researcher decide whether observations are dependable or have occurred by error (Weiers, 2011). 
Consequently, "inferential statistics is used to make inferences from a sample data to a more general condition of the population" (Weiers, 2011). To facilitate data analysis, the researcher used statistical software known as SPSS. The researcher carried out regression analysis Weiers (2011) to establish whether the independent variables risk management, leadership, experience and expertise, project size influence the dependent variable project success. The following regression model was adopted for this study:

$\mathrm{Y}=\mathrm{B}_{0}+\mathrm{B}_{1} \mathrm{X}_{1}+\mathrm{B}_{2} \mathrm{X}_{2}+\mathrm{B}_{3} \mathrm{X}_{3}+\mathrm{B}_{4} \mathrm{X}_{4}+\mathrm{e}$ Equation 1

Where:

$\mathrm{Y}=$ Project success;

$\mathrm{X}_{1}=$ Risk management;

$\mathrm{X}_{2}=$ Leadership;

$\mathrm{X}_{3}=$ Experience and expertise;

$\mathrm{X}_{4}=$ Project size;

$\mathrm{B}_{0}=$ Constant; and

$\mathrm{B}_{1}, \mathrm{~B}_{2}, \mathrm{~B}_{3}$, and $\mathrm{B}_{4}$ are correlation coefficients; and

$\mathrm{e}=$ Error term

The regression analysis model summary contained the R-value which showed the relationship between the variables under study, whereas the $\mathrm{R}$ square showed the number of dependent variables capable of being explained by independent variables. Furthermore, analysis of variance (ANOVA) output showed whether the four factors risk management, leadership, experience and expertise, project size are together crucial on the project success by comparing the $\mathrm{P}$ values and $\mathrm{F}$ value, thereby indicating the significance of the entire model (Weiers, 2011). In addition, the researcher carried out correlation analysis (Weiers, 2011) to test the connection of all the key success determinants which included risk management, leadership, experience and expertise, project size, success criteria, and project success. The correlation coefficients were computed with the aid of SPSS, and the results were outlined in a correlation matrix that contains the p-value of each of the relationships outlined above (Weiers, 2011). In the two-tailed test, the level of significance was at 0.01 .

Validity and Reliability Considerations: Saunders, Lewis and Thornhill (2012) explain validity as a measure of whether the findings are really about what they represent whereas reliability is the degree to which consistent results are obtained when the instrument is used to collect data. Various structured items in the instrument ensured content validity, and external validity was achieved by conducting a pre-trial of the instrument before the actual data collection exercise in which the researcher tested for reliability and validity (Cohen, Manion and Morrison, 2011). Further, the researcher used a variety of questions in testing the same concept to ensure the reliability of the (Babbie, 2014) and subsequently calculated Cronbach's Alpha to establish how items in the questionnaire were related (Nunnally and Bernisten, 2010). Bias is any likelihood that hinders the objective and impartial analysis of action and could occur in any phase when conducting research (Pannucci and Wilkins, 2010). According to Saunders, Lewis and Thornhill (2012), the bias in a study manifests itself in various forms including disability, ethnicity, gender as well as age. To avoid the influence of bias in this study, the researcher ensured that the language used was appropriate and that it did not have a discriminatory tone (Saunders, Lewis and Thornhill, 2012). Further, the researcher implemented the concepts of research ethics to eliminate biases associated with research (Saunders, Lewis and Thornhill, 2012).

Lastly, the researcher engaged the respondents voluntarily and gave them ample time and freedom to fill the questionnaire at their convenience to minimize study participant bias (Saunders, Lewis and Thornhill, 2012). According to Walton (2015), research ethics is specifically significant and manifests in cases where the respondents involved are people. The purpose of research ethics are three-fold, namely; to protect human respondents, to serve society and individual interests and to examine the ethical soundness of the study, including consenting and confidentiality (Walton, 2015). The researcher, in all circumstances, considered the ethical implications on all the respondents. The researcher put himself in the place of the participant and scanned for foreseeable threats to the respondents. Also, the researcher did not withhold any information and never misled the respondents. The respondents were also notified of the objectives of this research as well as being informed of voluntary participation and possible withdrawal if they wished to do so. Furthermore, because of the language barrier, the researcher did send out questionnaires in both languages French and English which was translated by a professional translator so that the questions can still have the 
same meaning in both languages and the respondent had a choice between the two to respond to his any of his choice.

\section{Results and Discussion of Findings}

Results: This section covers the analysis of the collected data and presents the analyzed results. The section is structured based on the objectives of the study, which were to:

i. Examine the influence of risk management on construction projects in DRC.

ii. Examine the influence of leadership on construction projects in DRC.

iii. Establish the influence of experience and expertise on construction projects in DRC.

iv. Examine the influence of project size on construction projects in DRC.

The demographics data provides additional information about the subjects of a research project and helps a researcher to comprehend better a situation that is under consideration (Saunders, Lewis and Thornhill, 2016). Demographic data in this study comprised of years of experience, the company, highest educational qualifications, the nationality of construction staff, location of a construction project, and functional area of construction staff was gathered during the survey. The statements and questions on the research instrument were measured using the Likert-like scale.

Correlation Analysis: The correlation analysis results for the main variables risk management, leadership, experience and expertise, project size, and success of a project are shown in Table 4.20. A correlation analysis demonstrates the existence of a relationship between variables under investigation (Weiers, 2011). Pearson Correlation ( $\mathrm{r}$ ) is used to illustrate the presence of a linear relationship among the variables under consideration in a study (Weiers, 2011). In Table 4.20, the double asterisk means that in a two-tailed test, the correlation is significant at 0.01 . The results show that there is a moderate positive correlation between risk management and project size $\left(\mathrm{r}=0.591^{* *}\right)$; and between risk management and success criteria $\left(\mathrm{r}=0.482^{* *}\right)$. The findings also show a weak positive correlation between risk management and experience and expertise $\left(r=0.0 .282^{* *}\right)$; and between risk management and project success $\left(r=0.248^{* *}\right)$.

However, the results show a weak negative correlation $\left(\mathrm{r}=-0.062^{* *}\right)$ between risk management and leadership. Further, the correlations analysis results show very weak negative relationships between leadership and experience and expertise $\left(r=-0.134^{* *}\right)$; leadership and success criteria $\left(r=-0.030^{* *}\right)$; leadership and project success $\left(\mathrm{r}=-0.092^{* *}\right)$. A weak positive relationship is also found to exist between leadership and project size $\left(r=0.021^{* *}\right)$. In addition, the results show moderate positive correlations between experience and expertise and success criteria $\left(r=0.549^{* *}\right)$; and experience and expertise and project success $\left(\mathrm{r}=0.532^{* *}\right)$. It is further established from the findings that there exists a weak positive relationship between experience and expertise and project size $\left(r=0.348^{* *}\right)$. Lastly, a fairly strong positive relationship was found to exist between project size and success criteria $\left(r=0.617^{* *}\right)$; and a fairly moderate positive relationship between project size and project success $\left(r=0.452^{* *}\right)$.

Table 4.20: Correlation Analysis

\begin{tabular}{|c|c|c|c|c|c|c|c|}
\hline & & $\begin{array}{l}\text { Risk } \\
\text { Management }\end{array}$ & Leadership & $\begin{array}{l}\text { Experience } \\
\text { and } \\
\text { Expertise }\end{array}$ & $\begin{array}{l}\text { Project } \\
\text { Size }\end{array}$ & $\begin{array}{l}\text { Success } \\
\text { Criteria }\end{array}$ & $\begin{array}{l}\text { Project } \\
\text { Success }\end{array}$ \\
\hline & $\begin{array}{l}\text { Pearson } \\
\text { Correlation }\end{array}$ & 1 & -0.062 & $0.282^{* *}$ & $0.591^{* *}$ & $0.482^{* *}$ & $0.248^{* *}$ \\
\hline Risk & $(\mathrm{r})$ & & & & & & \\
\hline \multirow[t]{3}{*}{ Management } & $\begin{array}{l}\text { Sig. } \\
\text { tailed) }\end{array}$ & & 0.450 & 0.000 & 0.000 & 0.000 & 0.002 \\
\hline & $\mathrm{N}$ & 150 & 150 & 150 & 150 & 150 & 150 \\
\hline & $\begin{array}{l}\text { Pearson } \\
\text { Correlation }\end{array}$ & -0.062 & 1 & -0.134 & 0.021 & -0.030 & -0.092 \\
\hline Leadership & $\begin{array}{l}(\mathrm{r}) \\
\text { Sig. } \\
\text { tailed) }\end{array}$ & 0.450 & & 0.102 & 0.799 & 0.717 & 0.261 \\
\hline
\end{tabular}




\section{Vol. 13, No. 2, pp. 16-34, June 2021}

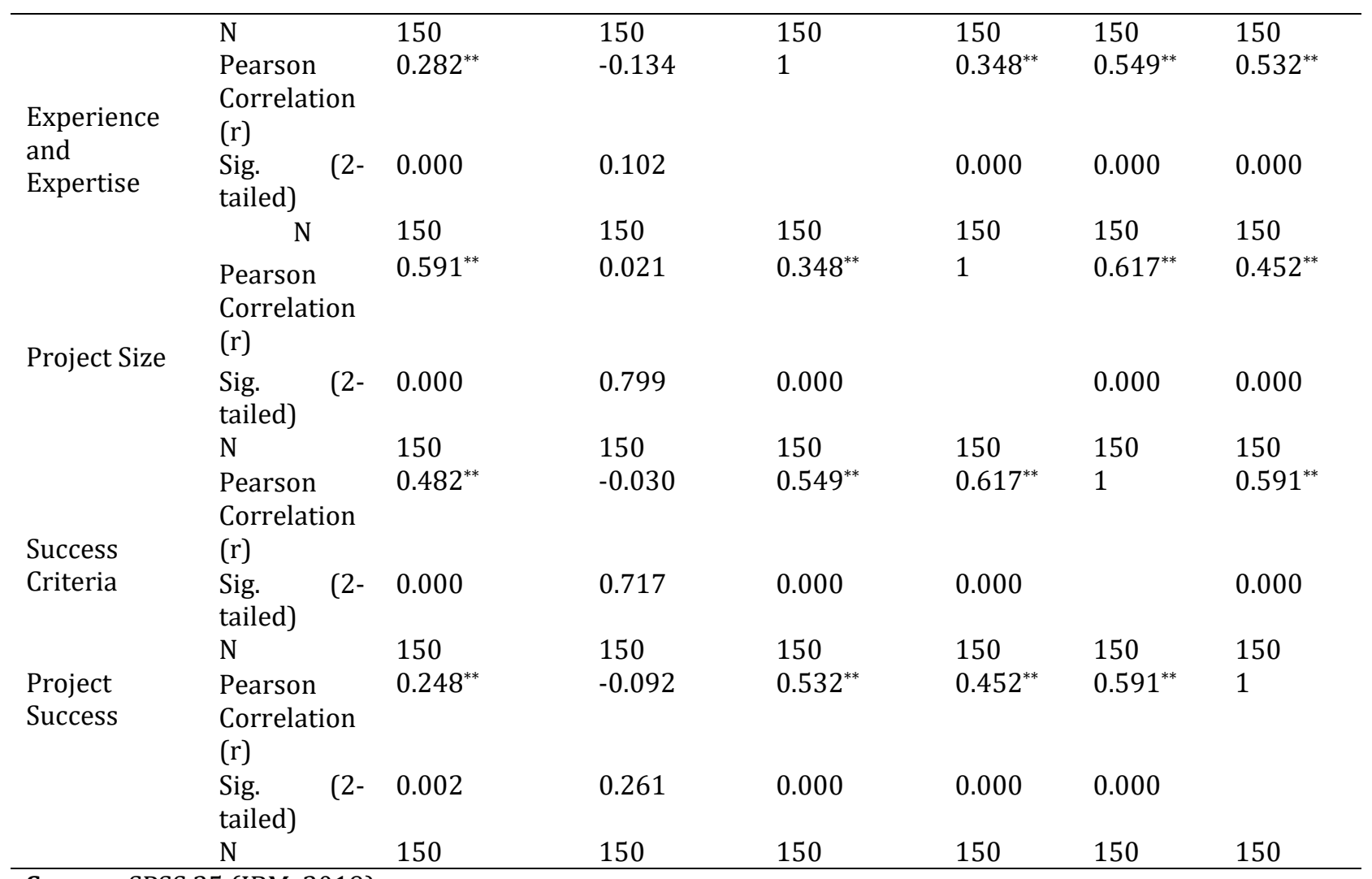

Source: SPSS 25 (IBM, 2019)

Regression Analysis: Regression analysis was used to investigate whether the independent variables risk management, leadership, experience and expertise, project size influence the dependent variable project success. The following regression model was adopted for this study:

$\mathrm{Y}=\mathrm{B}_{0}+\mathrm{B}_{1} \mathrm{X}_{1}+\mathrm{B}_{2} \mathrm{X}_{2}+\mathrm{B}_{3} \mathrm{X}_{3}+\mathrm{B}_{4} \mathrm{X}_{4}+\mathrm{e}$ Equation 1.

Where: $\mathrm{Y}=$ Project success;

$\mathrm{X}_{1}=$ Risk management;

$\mathrm{X}_{2}=$ Leadership;

$\mathrm{X}_{3}=$ Experience and expertise;

$\mathrm{X}_{4}=$ Project size;

$\mathrm{B}_{0}=$ Constant; and

$\mathrm{B}_{1}, \mathrm{~B}_{2}, \mathrm{~B}_{3}$, and $\mathrm{B}_{4}$ are correlation coefficients; and e = Error term

Table 4.21: Model Summary

\begin{tabular}{llllc}
\hline Model & $\mathrm{R}$ & RSquare & $\begin{array}{l}\text { Adjusted } \\
\text { RSquare }\end{array}$ & $\begin{array}{c}\text { Std. Error of the } \\
\text { Estimate }\end{array}$ \\
\hline 1 & 0.608 & 0.370 & 0.353 & 1.605 \\
\hline
\end{tabular}

As shown in the model summary in Table 4.21, there is a moderate positive relationship $(\mathrm{R}=0.608)$ between the dependent and the independent variables. The value of R Square 0.370 indicates that only 37.0 percent of project success could be explained by risk management, leadership, experience and expertise, project size the independent variables for the study. 
Table 4.22: Analysis of Variance (ANOVA)

\begin{tabular}{|c|c|c|c|c|c|}
\hline & $\begin{array}{l}\text { Sum of } \\
\text { Squares }\end{array}$ & df & Mean Square & $\mathrm{F}$ & Sig. \\
\hline Regression & 219.583 & 4 & 54.896 & 21.314 & 0.000 \\
\hline Residual & 373.457 & 145 & 2.576 & & \\
\hline Total & 593.040 & 149 & & & \\
\hline
\end{tabular}

ANOVA output is presented in Table 4.22. According to the ANOVA output, the four factors together (risk management, leadership, experience and expertise, project size) on project success are statistically significant given that the p-value was 0.000 which is not more than the standard 0.05 Therefore, the overall regression model was statistically significant.

Table 4.23: Coefficients

\begin{tabular}{|c|c|c|c|c|c|}
\hline & \multicolumn{2}{|c|}{$\begin{array}{l}\text { Unstandardised } \\
\text { Coefficients }\end{array}$} & \multirow{2}{*}{$\begin{array}{l}\text { Unstandardised } \\
\text { Coefficients } \\
\text { Beta }\end{array}$} & \multirow[b]{2}{*}{$t$} & \multirow[b]{2}{*}{ Sig. } \\
\hline & B & Std. Error & & & \\
\hline Constant & 0.100 & 3.406 & & 0.029 & 0.977 \\
\hline Risk management & -0.081 & 0.079 & -0.085 & -1.037 & 0.301 \\
\hline Leadership & -0.128 & 0.179 & -0.048 & -0.718 & 0.471 \\
\hline Experience and expertise & 0.879 & 0.147 & 0.426 & 5.966 & 0.000 \\
\hline Project size & 0.382 & 0.091 & 0.355 & 0.4204 & 0.000 \\
\hline
\end{tabular}

The coefficients in Table 4.23 above can be used to re-write the multiple regression model stated earlier in section 4.5. Hence, the model $\mathrm{Y}=\mathrm{B}_{0}+\mathrm{B}_{1} \mathrm{X}_{1}+\mathrm{B}_{2} \mathrm{X}_{2}+\mathrm{B}_{3} \mathrm{X}_{3}+\mathrm{B}_{4} \mathrm{X}_{4}+\mathrm{e}$. Equation 2

Becomes:

$\mathrm{Y}=0.100-0.081 \mathrm{X}_{1}-0.128 \mathrm{X}_{2}+0.879 \mathrm{X}_{3}+0.382 \mathrm{X}_{4}+\mathrm{e}$.

Equation 3

The regression equation above has shown that when all the factors (risk management, leadership, experience and expertise, project size) are kept at zero levels, project success will be equal to the constant or intercept 0.100. In addition, the findings also reveal that keeping all the other independent factors at a constant, a unit rise in risk management results in an $8.1 \%$ decrease in project success, and a unit rise in leadership results in a $12.8 \%$ project success decrease. Regression analysis results suggest that a unit increase in experience and expertise will result in an $87.9 \%$ increase in project success while a unit rise in project size results in a $38.2 \%$ increase in project success. This infers that at a 5\% level of significance, experience and expertise, and also project size are the most significant key success determinants in construction projects. The reliability of the instrument was assessed through the computation of Cronbach's alpha, as shown in Table 4.24. Cronbach's Alpha values that are below 0.7 imply that a research instrument is unreliable (Field, 2009). The Cronbach's alpha for the instrument used in this study was 0.736 and was subsequently considered to be reliable.

Table 4.24: Cronbach's Alpha Results

\begin{tabular}{|c|c|c|}
\hline Section & Measuring & Initial Cronbach's Alpha \\
\hline A & Demographics & Not Required \\
\hline B & 21 Study Questions & 0.736 \\
\hline
\end{tabular}




\section{Discussion of Findings}

How Does Risk Management Impact Construction Projects in the DRC? According to our findings, risk management influences construction projects in DRC. The study findings showed that political and governmental risks, economical risks, equipment risks, sub-contractor risks, construction risks, management risks and design risks negatively affect construction projects in DRC. However, the findings of the study did not show whether the owner-generated risks negatively affect construction projects in the DRC. According to the correlation analysis results, the larger the construction project size in the DRC, the greater the need for risk management in the project and subsequently the greater the chances of the project meeting success criteria. Further, the greater the need for risk management, the greater the need for experienced employees with the right expertise. More so, construction project success in the DRC could be enhanced by effective and efficient risk management because there are desirable aspects of risks.

Project risk can either be positive or negative and may affect the goals of the project regarding quality, cost, schedule and scope (Hosny, Ibrahim and Fraig, 2018). The results showed that leadership in construction projects in DRC might not result in the management of risks effectively and efficiently. Despite the results from the analysis failing to show the significance of risk management, the results from descriptive statistics and correlation did confirm the significance of risk management. Hosny, Ibrahim and Fraig (2018) explained that the success of construction projects increases when there is a framework on risk management. The authors' study on construction projects' risk management framework suggests that identified risks have to be prioritized for the contractors to have an effective risk response. An effective risk management framework is crucial in minimizing negative risks while enhancing positive risks and eventually resulting in the delivery of the construction project as it was intended based on the iron triangle framework (Hosny, Ibrahim and Fraig, 2018). It is thus inferred that effectively managing risks increases the chances of a construction project being successful.

How Does Leadership Impact Construction Projects? The findings above show that leadership impacts construction projects in the DRC. According to the results, transactional leadership positively affects construction projects in the DRC, while transformational leadership does not positively affect construction projects in the DRC. The correlation analysis results showed that large construction projects in DRC demand effective and efficient leadership. A positive relationship between transactional leadership and project success was established in the study by Liphadzi, Aigbavboa and Thwala (2015). The findings of this study concur with their findings. Consequently, this may explain the correlation analysis results that showed that project leadership in construction projects in the DRC does not amount to experience and expertise or the meeting of success criteria or project success. Although the regression analysis results do not confirm the value of leadership in construction projects, transactional leadership has been established to influence the success of construction projects. Effective and efficient leadership in large construction projects is necessary for their success and in meeting the success criteria (Tabassi et al., 2016). It may be concluded that effective and efficient leadership, including transactional leadership, would affect construction project success in the DRC.

How Do Experience and Expertise Impact Construction Projects? Findings also show that experience and expertise influence the success of construction projects in DRC. A project that is handled by experienced staff with the relevant in DRC is more likely to be successful based on the correlation analysis results. This also means that the success criteria may be highly met. Niazi and Painting (2017) stated that poor contractor experience is a factor that results in cost overruns in development projects. Furthermore, Hosny, Ibrahim and Fraig (2018) associated experience with the likelihood of having a successful construction project. In another study, Abbas, Din and Farooqui (2016) recommended construction project managers be experienced to effectively coordinate the various actors in the implementation of the project. Project management expertise should include formal skills, emotional intelligence, managerial skills and interpersonal abilities. Therefore, the more the experience and expertise of construction project staff in the DRC, the more likely the project success criteria would be met, and the more likely the project would be successful.

How Does Project Size Impact Construction Projects? The findings show that project size influences the success of construction projects in DRC. It was established that smaller-sized and medium-sized construction 
projects in the DRC are more successful. However, the results show that mega-sized construction projects in the DRC are not more successful. According to the correlation analysis results, the size of a construction project and project success criteria in DRC are positively related. Similarly, the size of the project and project success in DRC are positively related. Furthermore, the regression analysis results confirm the importance of project size as a key success factor for construction projects in developing countries like DRC. Mišić and Radujković (2015) explained that megaprojects are risky and have cost overruns of over $50 \%$, and turn to have a delivery failure as high as $66 \%$ and these projects may not produce the intended societal benefits. In addition, Mišić and Radujković (2015) stated that the key players of every project are people and that the delivery of mega projects requires competent project managers. Therefore, smaller-sized and medium-sized construction projects in the DRC are more successful, while mega projects in the DRC may not be very successful due to inadequate experience and expertise.

\section{Conclusion and Recommendations}

Conclusion: Based on the preceding discussion, the following are conclusions that can be drawn:

- Effective and efficient risk management enhances the success of construction projects.

- Effective and efficient leadership, including transactional leadership, would affect construction project success.

- The more the experience and expertise of construction project staff, the more likely the project success criteria would be met, and the more likely the project would be successful.

- Smaller-sized and medium-sized construction projects are more successful, while mega projects may not be very successful due to inadequate experience and expertise.

\section{Recommendations}

Recommendations on the Key Success Factors for Construction Projects in Developing Countries such as the DRC: The following are recommendations made based on the findings of this study regarding CSFs in construction projects in DRC:

- Continually embark on effectively and efficiently managing risks in construction projects in developing countries.

- Leadership in developing countries concerning construction projects should be effective and efficient.

- Developing countries should be able to engage mostly experienced staff with the right expertise in construction projects.

Continually Embark on Effectively and Efficiently Managing Risks in Construction Projects: Firstly, those responsible for managing construction projects in development should embark on efficiently and effectively, managing risks by ensuring that risk management matches project size. This proposal is supported by Silva, Warnakulasooriya and Arachchige (2015), who explained that risks in the construction industry are large and project success could be enhanced through continuous effective and efficient risk management. Therefore, by continually embarking on effectively and efficiently managing risks, both the desirable and undesirable aspects of risk could be harnessed for the project's success.

Ensure Effective and Efficient Leadership in Construction Projects: Secondly, developing countries should have those managing construction projects exhibit leadership that is highly effective and efficient. The type and scale of a construction project may require a specific leadership style. A similar proposal was made by Liphadzi, Aigbavboa and Thwala (2015) who established that transactional leadership influences the success of construction projects. Therefore, by ensuring effective and efficient leadership in construction projects, project success may be enhanced.

Engage Mostly Experienced Staff with the Right Expertise in Construction Projects: Thirdly, developing countries should engage experienced staff with appropriate expertise to undertake construction projects. It was established that staff with appropriate experience and expertise are a key success factor as far as construction projects are concerned. The level of staffing should match the project size. Niazi and Painting 
(2017) stated that poor contractor experience is a factor that results in cost overrun in development projects while Hosny, Ibrahim and Fraig (2018) explained that experience affects construction projects. Therefore, by engaging mostly experienced staff with the right expertise in construction projects, project success may be enhanced. This study has made an additional contribution to the available literature concerning CSFs in construction projects and in particular, in third world countries. The fact that related studies may have been done elsewhere and more so in developed countries does not mean that the findings of such studies can be generalized to represent the situation in the developing countries.

This study was necessary to be conducted to understand the situation in the context of developing countries. Time constraints might be one major limitation encountered by the researcher. The researcher, however, mitigated this by working beyond normal working hours and travelling during holiday time to collect data. The study's validity may have also been influenced by inaccurate data, particularly which was obtained from secondary sources as verification of these sources could not be done wholly. Also, it was not possible to cover the whole country due to its vastness. However, the researcher collected data from all spheres of the country, which ensured a good representation of the population. The following considerations should be made when considering further research on the key success factors: The Impact of construction project managed by external resources / foreign investment. Positive or negative impact growth in the Developing Countries industry; Evaluation of key success determinants for construction projects in DRC using qualitative interviews; Evaluation of key success determinants for large and complex construction projects in the DRC; The impact of transformational leadership in Construction Project in the DRC; and How can the risk that has been identified be mitigated going forward?

\section{References}

Abbas, A., Din, Z. U. \& Farooqui, R. (2016). Achieving greater project success \& profitability through preconstruction planning: A case-based study, Procedia Engineering, 145(1), 804-811.

Adams, J., Khan, H. T. \& Raeside, R. (2014). Research methods for graduate business and social science students. $2^{\text {nd }}$ Ed. New Delhi: Sage.

Adeer, H. J., Mellenbergh, G. J. \& Hand, D. J. (2011). Advising on research methods: A consultant's companion. Huizen: Johannes van Kessel Publishing.

Afolabi, A., Ibem, E., Aduwo, E., Tunji-Olayeni, P. \& Oluwunmi, O. (2019). Critical Success Factors (CSFs) for eProcurement Adoption in the Nigerian Construction Industry. Buildings, 9(2), 47-65.

ANAPI. (2016). Major projects awaiting fundings - DR Congo National Investment Promotion Agency. [Online] Investindrc.cd. Available at: https://www.investindrc.cd/en/investment-guide/major-projectsawaiting-fundings [Accessed 23 Dec. 2018].

Alashwal, A., Fareed, N. \& Al-Obaidi, K. (2017). Determining success criteria and success factors for international construction projects for Malaysian contractors, Construction Economics \& Building, $17(2), 62-80$.

Alias, Z., Zawawi, E., Yusof, K. \& Aris, N. (2014). Determining critical success factors of project management practice: A conceptual framework. Procedia - Social and Behavioral Sciences, 153(1), 61-69.

Aneesha, K. \& Haridharan, M. K. (2017). Ranking the project management success factors for construction projects in South India, in IOP Conference Series: Earth and Environmental Science.

Akeke, N. I., Akeke, A. R. \& Awolusi, O. D. (2015). The Effect of job satisfaction on organizational commitment among the non-academic staff of tertiary institutions in Ekiti State, Nigeria, International Journal of Interdisciplinary Research Method, 2(1), 25-39.

Araszkiewicz, K. (2015). Application of critical chain management in construction projects schedules in a multi-project environment: A case study, Procedia Engineering, 182(1), 33-41.

Aritz, J. \& Walker, R. (2014). Leadership styles in multicultural groups: Americans and East Asians working together. Journal of Business Communication, 51(1), 72-92.

Awolusi, 0. D. (2012). The effects of mergers and acquisitions on Business Performance in the Nigerian banking industry: an empirical analysis, International Journal of Business Performance Management, 13(3/4), 366-385.

Awolusi, O. D. (2021). Economic Growth and Socioeconomic Sustainability in BRICS Countries: A Vector Error Correction Modeling Approach, Journal of Economics and Behavioral Studies, 13(3), 1-23.

Babbie, E. R. (2014). The practice of social research. 14th ed. Australia: South-Western. 
Babalola, H. \& Ojo, O. (2016). An Investigation into Factors Affecting the Performance of Public Construction Projects in Ondo State, Southwestern, Nigeria. Civil and Environmental Research, 8(1), 72-79.

Banihashemi, S., Hosseini, M., Golizadeh, H. \& Sankaran, S. (2017). Critical success factors (CSFs) for integration of sustainability into construction project management practices in developing countries, International Journal of Project Management, 35(6), 1103-1119.

Barnes, M. (1988). Construction project management (Book Review), Construction Management \& Economics, 4(1), 81-97.

Baron, L. \& Parent, E. (2015). Developing authentic leadership within a training context: Three phenomena supporting the individual development process. Journal of Leadership \& Organizational Studies, 22(1), 37-53.

Belay, A. M. \& Torp, O. (2017). Do Longer Projects Have Larger Cost Deviation Than Shorter Construction Projects? Procedia Engineering, 196(1), 262-269.

Brace, I. (2008). Questionnaire design: How to plan, structure and write survey material for effective market research. $2^{\text {nd }}$ ed. London: Kogan Page Publishers.

Damoa, I. S., Akwei, C. \& Mouzughi, A. (2015). Causes of government project failure in developing countries Focus on Ghana. British Academy of Management.

Doulabi, R. Z. \& Asnaashari, E. (2016). Identifying success factors of healthcare facility construction projects in Iran, Procedia Engineering, 164(1), 409- 415.

Das, D. \& Ngacho, C. (2017). Critical success factors influencing the performance of development projects: An empirical study of Constituency Development Fund projects in Kenya, IIMB Management Review, 29(1), 276-293.

Ceric, A. (2013). The Principal-Agent Theory and the Role of Project Managers in Construction: Guidelines for Future Research. [Online] Irbnet.de. Available at: http://www.irbnet.de/daten/iconda/CIB_DC25687.pdf [Accessed 23 Feb. 2019].

Chikere, C. C. \& Nwoka, J. (2015). The systems theory of management in modern-day organizations - A study of Aldgate Congress Resort Limited Port Harcourt, International Journal of Scientific and Research Publications, 5(9), 1-7.

Chepkemoi, J. (2018). The Largest Countries in Africa by Land Area. [Online] WorldAtlas. Available at: https://www.worldatlas.com/articles/which-are-the-10-largest-countries-of-africa-by-size.html [Accessed 24 May 2019].

Cheong Yong, Y. \& Emma Mustaffa, N. (2012). Analysis of factors critical to construction project success in Malaysia. Engineering, Construction and Architectural Management, 19(5), 543-556.

Clowes, W. (2018). Bloomberg -. [Online] Bloomberg.com. Available at: https://www.bloomberg.com/news/articles/2018-06-13/congo-plans-to-start-13-9-billionhydropower-project-this-year [Accessed 2 May 2019].

Cohen, L., Manion, L. \& Morrison, K. (2011). Research methods in education. $7^{\text {th }}$ ed. London: Routledge.

Collis, J. \& Hussey, R. (2003). Business Research: A practical guide for undergraduate and postgraduate students. New York, USA: Palgrave Macmillan.

Crawford, L. (2000). Profiling the competent project manager, in Project management research at the turn of the Millenium. Paris, France: Project Management Institute. Available at: https://www.pmi.org/learning/library/profiling-competent-project-manager-8524 [Accessed: 10 July 2018].

Edwards, R. \& Holland, J. (2013). What is qualitative interviewing? $1^{\text {st }}$ ed. London: Bloomsbury Publishing Plc.

El-Karim, M. S., El Nawawy, O. A. \& Abdel-Alim, A. M. (2017). Identification and assessment of risk factors affecting construction projects, HBRC Journal, 13(1), 202-216.

Easterby-Smith, M., Thorpe, R. \& Jackson, P. (2012). Management Research, $4^{\text {th }}$ edition, London: SAGE Publications.

Field, A. (2009). Discovering statistics using SPSS. London: SAGE.

Giltinane, L. (2013). Leadership styles and theories. Nursing Standard, 27(41), 35-39.

Gunduz, M. \& Yahya, A. M. A. (2015). Analysis of project success factors in the construction industry, Technological and Economic Development of Economy, 24(1), 67-80.

Hattangadi, V. (2016). Historical and contemporary theories of management, International Journal of Business and Management Invention, 5(10), 48-53.

Hosny, H. E., Ibrahim, A. H. \& Fraig, R. F. (2018). Risk management framework for continuous flight auger piles construction in Egypt, Alexandria Engineering Journal, 57(1), 2667-2677. 
Ibm.com. (2019). SPSS software. IBM Corporation. [Online] Available at: http://www.ibm.com/analytics/us/en/technology/spss/ [Accessed 23 Jan. 2019].

Iram, N., Khan, B. \& Sheran, A. W. (2016). Critical factors influencing the project success: An analysis of projects in manufacturing and construction in Pakistan. Arabian Journal of Business and Management Review (Oman Chapter), 6(2), 234-245.

Joo, B. \& Nimon, K. (2014). Two of a kind? A canonical correlational study of transformational leadership and authentic leadership. European Journal of Training \& Development, 38(6), 570-587.

Kogan, N. \& Lee, K. J. (2014). Exploratory research on success factors and challenges of smart city projects. Asia Pacific Journal of Information Systems, 24(2), 141-189.

Leedy, P. \& Ormrod, J. (2015). Practical Research: Planning and Design. 11th Ed. New Jersey: Pearson Education International.

Liphadzi, M., Aigbavboa, C. \& Thwala, W. (2015). Relationship between leadership styles and project success in the South Africa construction industry, Procedia Engineering, 123(1), 284-290.

Likert, R. (1932). A technique for the measurement of attitudes. Archives of Psychology, 140(1), 1-55.

Long, N., Ogunlana, S., Quang, T. \& Lam, K. (2004). Large construction projects in developing countries: a case study from Vietnam. International Journal of Project Management, 22(7), 553-561.

Mahmood, S. \& Shahrukh. (2012). Exploring the Critical Success Factors of Construction Companies of Developing Countries. The International Journal's Research Journal of Social Science \& Management, $1(1), 8-14$.

Mavetera, N., Sekhabisa, K., Mavetera, C. \& Choga, I. (2015). Factors influencing the success of construction projects by emerging contractors in South Africa: a case of Mahikend area. Corporate Ownership and Control, 13(1), 234-256.

Men, R. (2014). Internal reputation management: The impact of authentic leadership and transparent communication, Corporate Reputation Review, 17(4), 254-272.

McNabb, D. E. (2016). Research methods for political science: Quantitative and qualitative approaches. $2^{\text {nd }} \mathrm{Ed}$. New York, USA: Routledge.

Misic, S. \& Radujkovic, M. (2015). Critical drivers of megaprojects success and failure. Procedia Engineering, 122(1), 71-80.

Montequin, V. R., Cousillas, S. M. \& Villanueva, J. (2016). Success factors and failure causes in projects: Analysis of cluster patterns using self-organizing maps, Procedia Computer Science, 100(1), 440-448.

Niazi, G. A. \& Painting, N. (2017). Significant factors causing cost overruns in the construction industry in Afghanistan, Procedia Engineering, 182(1), 510-517.

Nunnally, J. C. \& Bernstein, I. H. (2010). Psychometric theory. New Delhi: Tata McGraw-Hill Ed.

Odimabo, O. \& Oduoza, C. F. (2018). Guidelines to aid project managers in conceptualizing and implementing risk management in building projects, Procedia Manufacturing, 17(1), 515-522.

Odimabo, O. \& Oduoza, C. (2013). Risk Assessment Framework for Building Construction Projects in Developing Countries. International Journal of Construction Engineering and Management, 5(2), 143154.

Ojiako, U., Johansen, E. \& Greenwood, D. (2008). A qualitative re-construction of project measurement criteria, Industrial Management \& Data Systems, 108(3), 405-417.

Olayisade, A. \& Awolusi, O. D. (2021). The Effect of Leadership Styles on Employee's Productivity in the Nigerian Oil and Gas Industry, Information Management and Business Review, 13(1), 47-64.

Pannucci, C. J. \& Wilkins, E. G. (2010). Identifying and avoiding bias in research. Plastic and reconstructive surgery, 126(2), 619-625.

Pinto, J. K. \& Slevin, D. P. (1988). Critical success factors across the project life cycle: Definitions and measurement techniques, Project Management Journal, 19(3), 67-75.

Project Management Institute (PMI). (2013). A guide to the project management body of knowledge (PMBOK ${ }^{\circledR}$ Guide), $5^{\text {th }}$ ed. Project Management Institute.

Rajasekaran, A. G. \& Valli, P. (2014). Analysis of the success factors influencing a construction project, International Journal of Engineering \& Applied Sciences, 6(1), 21-21.

Ramlee, N., Tammy, N. J., Noor, R. N., Musir, A. A., Karim, N. A., Chan, H. B. \& Nasir, S. R. (2016). Critical success factors for construction project, AIP Conference Proceedings, 1774(1), 1-7.

Rezek, M. (2013). Leading a cross-cultural workplace. [Online] http://www.chinabusinessreview.com/leading-a-cross-cultural-workplace/[Accessed 23 Jan. 2019] 
Risath, A. \& Siriwardana, C. (2018). Assessment of Critical Success Factors (CSFs) for the deployment of construction risk management practices in Srilanka. International Journal of Civil Engineering, 7(5), $1-12$.

Sanvido, V., Grobler, F., Parfitt, K. \& Guvenis, M. (1992). Critical Success Factors for Construction Projects. Journal of Construction Engineering and Management, 118(1), 94-111.

Saunders, M., Lewis, P. \& Thornhill, A. (2012). Research methods for business students. $6^{\text {th }}$ ed. London: Pearson Publishers.

Saunders, M., Lewis, P. \& Thornhill, A. (2016). Research Methods for Business Students. 7th ed. Essex: Pearson Education Ltd.

Serrador, P. \& Pinto, J. K. (2015). Does agile work? - A quantitative analysis of agile project success. International Journal of Project Management, (33)5, 1040-1051.

Silva, G., Warnakulasooriya, B. \& Arachchige, B. (2016). Critical success factors: En route for the success of construction projects, International Journal of Business and Social Science, 7(3), 256-267.

Tabassi, A. A., Argyropoulou, M., Roufechaei, K. M. \& Argyropoulou, R. (2016). Leadership behavior of project managers in sustainable construction projects, Procedia Computer Science, 100(1), 724-730.

Tengan, C. \& Aigbavboa, C. (2017). Level of stakeholder engagement and participation in monitoring and evaluation of construction projects in Ghana, Procedia Engineering, 196(1), 630-637.

Tesfaye, E., Lemma, T., Berhan, E. \& Beshah, B. (2017). Key project planning processes affecting project success. International Journal for Quality Research, 11(1), 159-171.

Tshik, M. (2015). Critical success factors for infrastructure construction projects in South Africa: project management, and construction. Civil Engineering = Siviele Ingenieurswese, 23(6), 19-24.

Tsiga, Z., Emes, M. \& Smith, A. (2017). Critical success factors for projects in the petroleum industry, Procedia Computer Science, 121, 224-231.

United Nations. (2018). Least Developed Countries (LDCs) | Economic Analysis \& Policy Division. [Online] Available at: https://www.un.org/development/desa/dpad/least-developed-country-category.html [Accessed 23 Dec. 2018].

Wadongo, B. \& Abdel-Kader, M. (2014). Contingency theory, performance management and organizational effectiveness in the third sector: A theoretical framework, Journal of Facilities Management, 63(6), 680-703.

Williams, T. (2016). Identifying success factors in construction projects: A case study, Project Management Journal 2, 47(1), 97-112.

Wondimu, P. A., Hailemichael, E., Hosseini, A., Lohne, J., Torp, O. \& Laedre, O. (2016). Success factors for early contractor involvement (ECI) in public infrastructure projects, Energy Procedia, 96(1), 845-854.

Walton, N. (2015). What is research ethics? [Online] Available at: https://researchethics.ca/what-is-researchethics/[Accessed: 10 Jan. 2019].

Weiers, R. (2011). Introduction to business statistics. $7^{\text {th }}$ ed. Mason, OH: Cengage.

World Bank. (2018). Projects \& Programs_Democratic Republic of Congo. [Online] Available at: http://www.worldbank.org/en/country/drc/projects [Accessed 21 Dec. 2018].

Yujin, K. (2011). The pilot study in qualitative inquiry. Qualitative Social Work, 10(2), 190-206.

Yong, Y. \& Mustaffa, N. (2013). Critical success factors for Malaysian construction projects: An empirical assessment, Construction Management \& Economics, 31(9), 959-978.

Zidane, Y., Johansen, A., Andersen, B. \& Hoseini, E. (2015). Time thieves and bottlenecks in the Norwegian construction projects, Procedia Economics and Finance, 21(1), 486-493.

Nzekwe, J., Oledelo, E. \& Emoh, F. (2015). Project Failure as a Reoccuring Issue in Developing Countries: Focus on Anambra State, South-East Nigeria. [Online] Eajournals.org. Available at: http://www.eajournals.org/wp-content/uploads/Project-Failure-As-A-Reoccurring-Issue-In-

Developing-Countries.pdf [Accessed 28 Mar. 2019].

Zikmund, W. G. (2010). Business research methods. $8^{\text {th }}$ ed. Mason, OH: Cengage. 